\title{
Experimental Dynamical Analysis and Numerical Simulation of the Material Properties of Parts Made by Fused Deposition Modelling Technologies
}

\author{
Peter Ficzere ${ }^{1 *}$ \\ ${ }^{1}$ Department of Vehicle Elements and Vehicle-Structure Analysis, Faculty of Transportation Engineering and Vehicle Engineering, \\ Budapest University of Technology and Economics, H-1111 Budapest, Múegyetem rakpart 3., Hungary \\ * Corresponding author, e-mail: ficzere@kge.bme.hu
}

Received: 26 February 2019, Accepted: 13 May 2019, Published online: 28 June 2019

\begin{abstract}
In the recent years 3D printing became a hot topic, however it's hard to design parts without a deep understanding of the material properties. The usage of these materials in vehicles assumes the knowledge of the behavior in dynamical environment. The aim of this study is to estimate the modal parameters and the damping properties via experimental dynamic analysis of a part made from PLA. With the results we can provide data for the FEM softwares' input. After the numerical simulations the simulated results were compared to the measured data.
\end{abstract}

Keywords

experimental modal analysis, additive manufacturing, eigenfrequency, mode shapes, polymers, material law

\section{Introduction}

Additive manufacturing technologies being relatively new to the scene are evolving rapidly. And with it comes the drop of the expenses of the 3D printed products, making the technology more accessible for a larger audience (Ficzere and Torok, 2013; Ficzere et al. 2013).

At the same time importance of biodegradable plastic started rising, especially because environmental protection became an important factor (Bodnár, 2002). PLA (polylactic acid) is a popular solution and widely used mainly because it's low price.

The combination of this flexible technology and the environment friendly material foreshadows the rise of the additive manufacturing using PLA. For engineering usage, we need deeper understanding of the material properties (Ficzere et al., 2014). We researched the available literature about PLA's material properties. There are only a few papers that model these properties as well. For the same properties the studies show various results (Ficzere, 2016; Ficzere et al., 2018; Tisza et al., 2015). The aim for this study to learn more about the damping properties and the effects of different technological parameters on the material properties.

\section{Literature review}

Researching the available literature, we became certain that the orientation of the part in the 3D printer has a significant influence on the material properties: the "standing" test pieces' maximum tensile stress was considerably lower than in the other two cases (Tisza et al. 2015). The proportion varied presumably because of the different printing parameters. But it's clear that the parts printed in standing position only had 0.4-0.5 times the strength (Ficzere, 2016).

Perpendicular to the layers' plane the material behaves in a similar way (Tisza et al., 2015). Considering the results, it can be state that the parts produced by this method have orthotropic material properties.

\section{Methodology \\ Reviewing of the literature, experimental, production and application experiences show that parts made by additive manufacturing don't show isotropic material properties. The orthotropic nature can be explained by the dependence of orientation of the printing (Ficzere, 2016; Tisza et al., 2015). Experimental analyzes of parts made of polymers raise problems of the dynamic modeling (Kovács et al., 2018a).}


For every direction, we printed 3 specimens to check the reproducibility and eliminate errors of the printer. These printing directions can be seen in Fig. 1. So far, the two laying positions have been tested. We tested the parts as cantilevers. For excitation we used an impact hammer, and measured the response using accelerometers (Kovács et al., 2018b). The theoretical measurement set-up can be seen in Fig. 2.

Testing it as a cantilever we located the test piece's natural frequencies (bending and torsion), damping ratios and mode shapes in the $\mathrm{f}=0-850 \mathrm{~Hz}$ range. For every mode we checked if the mode shape is classical normal mode or not. As it is known classical normal modes' mode shapes show standing wave nature, and equivalent to the undamped system's mode shapes. Thus, the mathematical model is significantly simpler. We separated the detected mode shapes into 2 groups: bending and torsion modes. To identify the damping mechanism, we will define regression functions which express the damping factor's frequency dependence (Pápai, 2011). These functions have a direct connection to the damping factor's function known from rheology. The damping factor is the ratio of the loss modulus and the storage modulus. Generally, the loss modulus and the storage modulus are functions of the frequency, therefore the ratio is a function of the frequency.

\section{Direction of 3D printing}

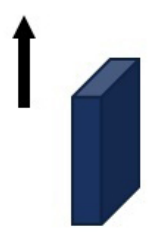

„A"

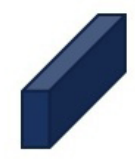

„B"

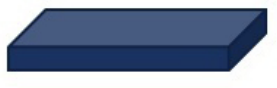

"C"
Fig. 1 Directions of printing
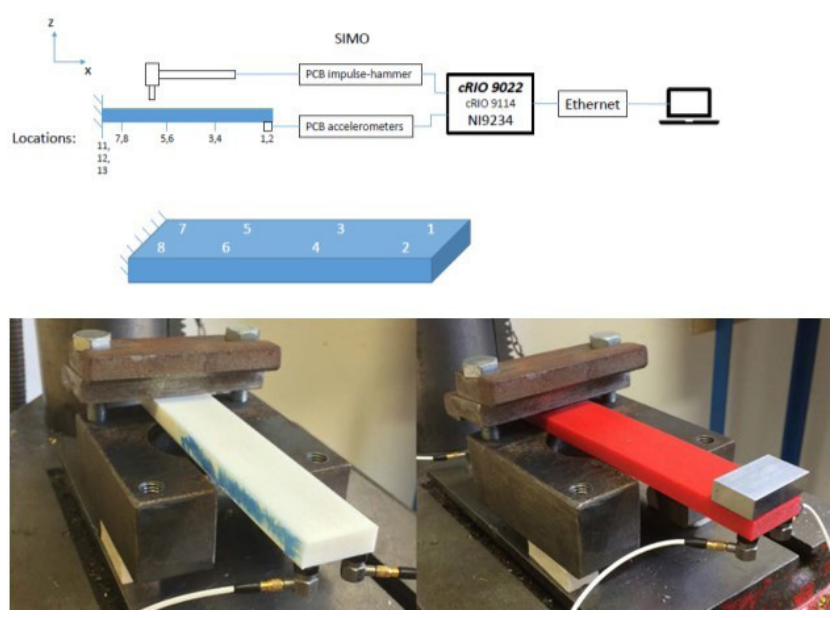

Fig. 2 Measurement set-up
Via iteration we will identify the material properties which makes the FEM model valid, and the difference between the FEM and EMA model's characteristics (Eigen frequency, damping factor, mode shapes) are the least.

In the next phase of the study the comparison will be made qualitatively. For the further project the FEM model's reduction will be done. We will learn what possibilities we have, to change the damping properties in the chosen FEM environment.

This paper demonstrates the results of a dynamical analysis on a prism. Three different parts are made, each printed in a different direction.

\subsection{Parameter estimation}

For the measured Frequency Response Function's (FRF from now) analytic approximation we used the partial fraction form Eq. (1):

$$
H(j \omega)=\sum_{i=1}^{n}\left[\frac{P_{i}}{j \omega-\lambda_{i}}+\frac{\bar{P}_{i}}{j \omega-\bar{\lambda}_{i}}\right]
$$

where $P_{i}$ residuum of mode $i\left[\frac{\mathrm{m} / \mathrm{sec}}{\mathrm{N}}\right], \lambda_{i}$ the complex eigenvalue of mode $i[\mathrm{rad} / \mathrm{sec}]$.

$\lambda_{i}=-\sigma_{i}+j \omega_{d, i}$

$\sigma_{i}$ modal damping of mode $i$; $\omega_{d, i}$ damped natural frequency of mode $i ; j$ imaginary part.

These modal parameters were estimated by the measure FRF. The individual modes are affecting the others (Fig. 3), the estimation is inaccurate. We need an optimizing function.

The method minimizes the

$\varepsilon\left(P_{i}, \lambda_{i}\right)=\sum_{r=1}^{N_{r}}\left(H\left(j \omega_{r}\right)-\hat{H}_{r}\right)^{2}$

least squares function. $\hat{H}_{r}$ is the measured and averaged FRF at angular frequency.

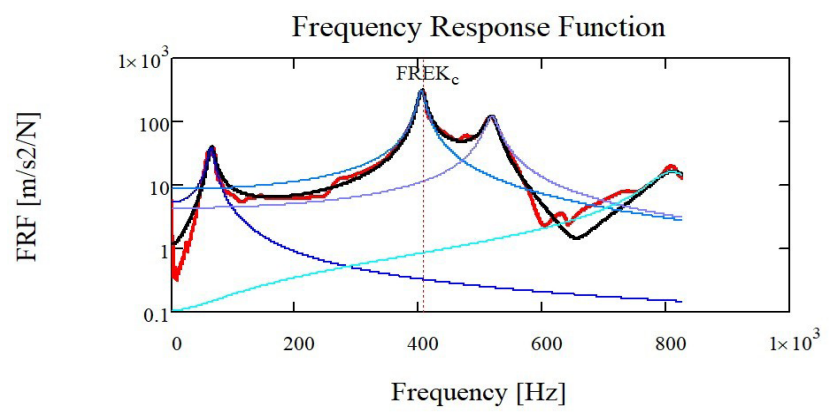

Fig. 3 The interference between individual modes 


\section{Results}

\subsection{Experimental results}

Fig. 4 shows the FRF of a part printed with method " $\mathrm{B}$ ", the laying case in the middle of Fig. 2. The frequency values belonging to the peaks of the curve indicate the own frequency.

We excite in a fixed point, and the response is measured also in locations 1 and 2 of the specimen (Fig. 3). The points belonging to peak FRF on the identical own frequency, the Nyquist plots belonging to the two response measurement locations indicate whether the two points reach the extreme position in phase or counterphase. The cursor in both cases is on the same point belonging to the own frequency. It is clear that the two points are approximately in counterphase, so the vibration image is of torsion character, otherwise we could have assumed bending vibration. In Fig. 5 the dominant modal circles can be seen. Further analysis has to be made to estimate the modes with smaller amplitude (near the origin).

Using this method, we could detect 4 natural frequencies frequency value belonging to the 4 peaks) as you can see in Table 1. For the classification we use the Nyquistplot of the FRF. (B - Bend, T - Torsion)

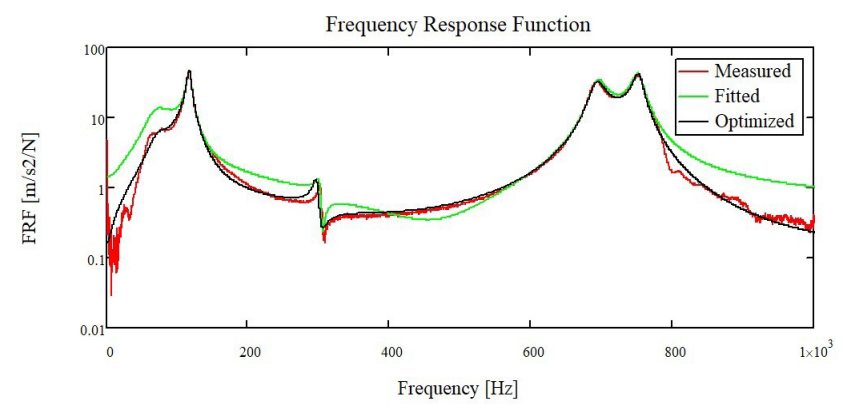

Fig. 4 FRF of part B1
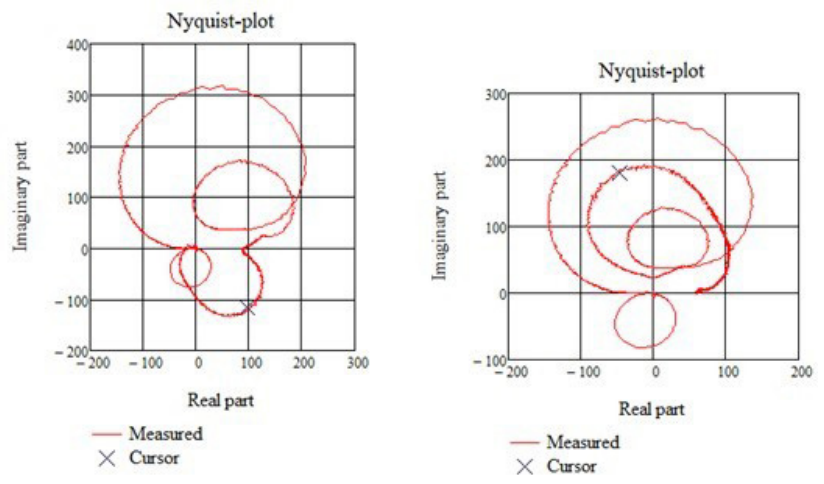

Fig. 5 Vibration image classification with Nyquist plots
Table 1 Experimental results

\begin{tabular}{lcccc}
\hline Mode i & 1 & 2 & 3 & 4 \\
\hline$f_{i}[\mathrm{~Hz}]$ & 116.87 & 304.58 & 692.03 & 762.96 \\
$\xi_{i}[\%]$ & 2.61 & 9.14 & 1.49 & 0.93 \\
Type & $\mathrm{B}$ & $\mathrm{T}$ & $\mathrm{T}$ & $\mathrm{B}$ \\
\hline
\end{tabular}

\subsection{Numerical simulation}

For the further investigation we have to make numerical simulations. The verification of the results is needed. The finite element model was built assembled with glued contact. The constraints were defined as a cantilever beam. After the definition of the contact, the boundary conditions and material properties the normal modes were investigated. Based on the theoretical background and the results of the experimental investigation we wait more type bending and torsion normal mode shapes, too (Fig. 6).

On other frequency we can find other bending shape (other inertia) can be seen in Fig. 7.

Increased the frequency we can detect the torsion mode shape (Fig. 8).

We can see, the numerically simulated results show the same shapes and values (Bending $115 \mathrm{~Hz}$, Torsion $327 \mathrm{~Hz}$ ).

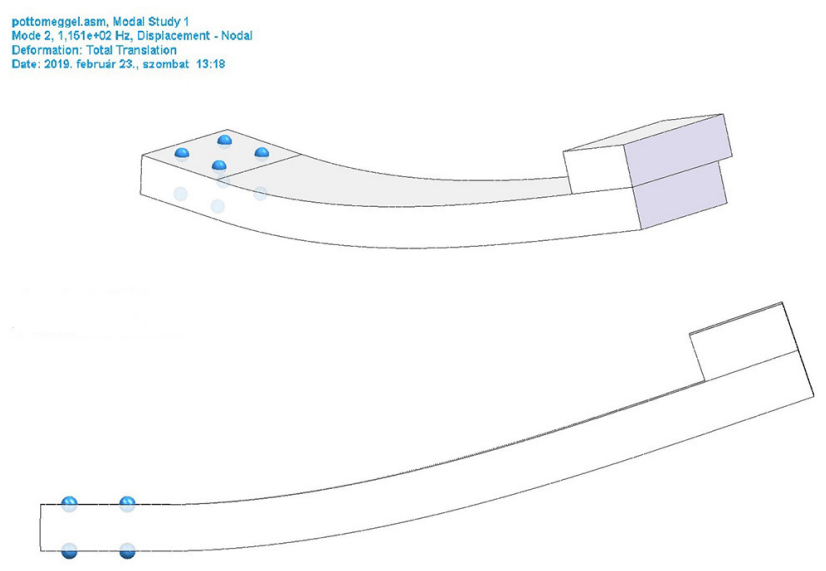

Fig. 6 Bending shape (axonometric and side view)

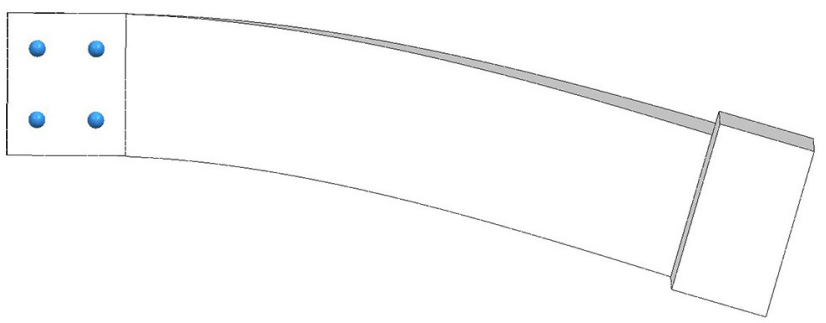

Fig. 7 Bending shape at higher frequency (top view) 


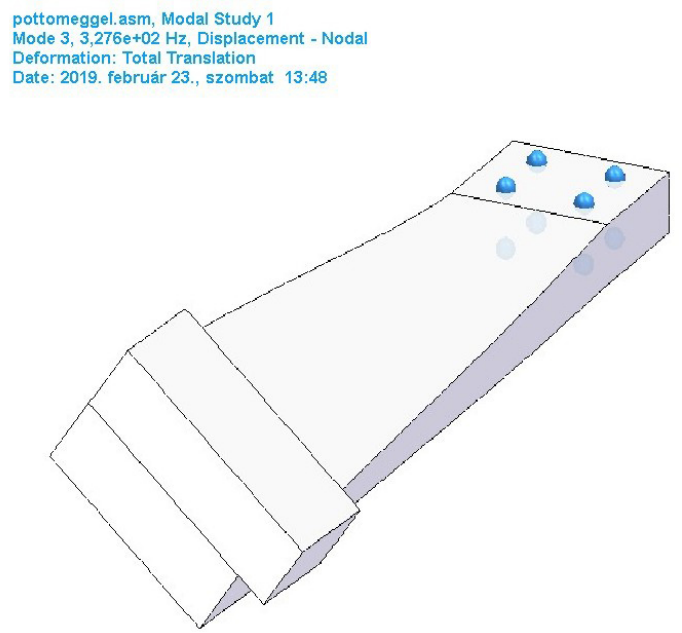

Fig. 8 Torsion shape (axonometric view)

\section{Discussion}

The results show little to no difference between the two laying parts ( $\mathrm{B}$ and $\mathrm{C}$ ). With the last measurements done we will be able to compare the different orientations. When processing the data, we suspected non-linearity of the material properties.

We can state the material model of elements produced by FDM technology in case of PLA materials follows fluid-type behavior (viscous-elastic behavior). Jeffrey-body, the construction is a serial connection of a Kelvin-Voight and a Newton body, so it is a fluid-type model. Sometimes it is called Fluid II. Model (Pápai, 2011). The Jeffrey-body can be seen in Fig. 9. We found that this model realizes a Rayleigh-shape with proportional damping behavior.

Based on the experimental results the PLA material shows anisotropic behavior, the damping parameters are changing in the function of the printing directions.

Based on the investigation we can state that the standard deviation of damping parameters of FRF functions determined by analytical approximation is in a great range.

Probably the clamping conditions must be changed. One of the possible solutions is the free hanging of the test specimens.

\section{References}

Bodnár, I. (2002) "Synthesis and investigation of potentially biodegradable, polylactic acid based polymers", PhD Thesis, University of Debrecen.

Ficzere, P. (2016) "Orthotrop anyagmodell alkalmazása additív gyártástechnológiával előállított alkatrész méretezése során" (Usage of orthotrop material law for additive manufacturing in part design), Gép, 67(5-6), pp. 78-81. (in Hungarian)

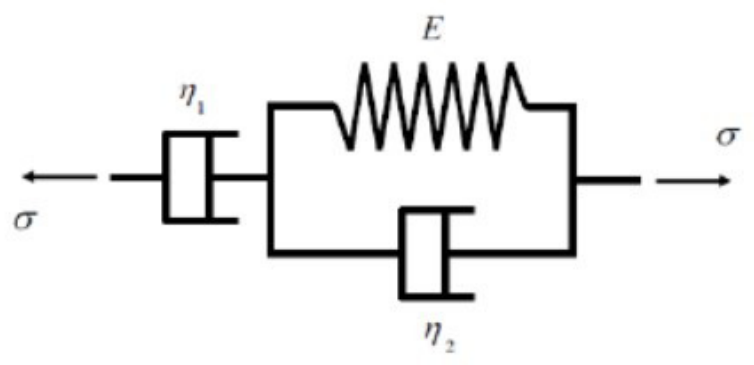

Fig. 9 Jeffrey-body material model

The experimental results must be verified by numerical simulation.

Generally, the Hooke's Law is applied, where to describe the behavior of the material, the determination of the Young Modulus is enough $(\sigma=\mathrm{E} \varepsilon)$. In orthotropic case, stiffness constant in the three printing directions is different. Based on my investigation the "Jeffrey-body" describes the behavior of the material more exactly, where the determination of the damping parameters is necessary.

From the creeping model of the "Jeffrey-body" it can be established that the material behavior could be characterized with a hysteresis curve, which is proportional to the damping parameters of the material. The curve generated from the peak-points of the hysteresis loops could describe the fatigue behavior of the material. The determination of the model parameters, fatigue investigation will be carried out.

\section{Acknowledgements}

These project results have been realized with a subsidy of the National Research Development and Innovation Office from the fund of NKIH. The title of the project is "Development of the New Generation of Production Technology for Individual Medical-Biological Implantation and Tools". Project identification No.: NVKP_16-1-2016-0022.

Ficzere, P., Borbás, L., Falk, Gy. (2018) "Additív gyártástechnológiák alkalmazhatósági vizsgálata testreszabott orvosi implantátumok méretezéséhez" (Material laws of additive manufacturing technologies used for design parameters of human implants production), Biomechanica Hungarica, 11(2), pp. 69-75, (in Hungarian). https://doi.org/10.17489/2018/2/10 
Ficzere, P., Borbás, L., Török, Á. (2013) "Economical investigation of rapid prototyping", International Journal For Traffic and Transport Engineering, 3(3), pp. 344-350.

https://doi.org/10.7708/ijtte.2013.3(3).09

Ficzere, P., Borbas, L., Torok, A. (2014) "Validation of Numerically Simulated Rapid-prototype Model by Photoelastic Coating", Acta Mechanica Slovaca, 18(1), pp. 14-24. https://doi.org/10.21496/ams.2014.002

Ficzere, P., Török, Á. (2013) "Gyorsprototípus gyártás gazdasági előnyei" (Economical advantages of Rapid Prototyping), In: OGÉT 2013 XXI Nemzetközi Gépészeti Találkozó, Arad, Romania, pp. 113117. (in Hungarian)

Kovács, B. Á., Ficzere, P., Borbas, L. (2018a) "Experimental dynamical analysis of specimens' material properties manufactured by additive technologies", In: 35th Danubia Adria Symposium On Advances In Experimental Mechanics, Sinaia, Romania, pp. 49-51.

Kovács, B. Á., Ficzere, P., Török, Á. (2018b) "PLA anyagból készült próbadarab anyagtulajdonságainak kísérleti dinamikai vizsgálata" (Experimental Dynamical Analysis of Test Pieces Material Properties Made by Additive Production Technologies), In: A XXIII. Fiatal Müszakiak Tudományos Ülésszak előadásai (Proceedeings of the XXIII. International Scientific Conference of Young Engineers), Cluj-Napoca, Romania, pp. 135-139. (in Hungarian)
Pápai, F. (2011) "Klasszikus normál módusú lengőrendszerek csillapítási modellezésének vizsgálata" (Classic standard-mode swing system attenuation modelling investigation), In: XI. Magyar Mechanikai Konferencia, MaMeK, (XI. Hungarian Mechanical Conference) Miskolc, Hungary, pp. 1-11. (in Hungarian)

Tisza, M., Kovács, P. Z., Tóth, D. (2015) "3D nyomtatás a jármüiparban" (3D printing in the automotive industry), In: MultiScience - XXIX. microCAD International Multidisciplinary Scientific Conference, Miskolc, Hungary, pp. 1-9. (in Hungarian), https://doi.org/10.26649/musci.2015.061 